\title{
Stability of apomorphine in solutions containing selected antioxidant agents
}

This article was published in the following Dove Press journal:

Drug Design, Development and Therapy

3 October 2016

Number of times this article has been viewed

\section{Zen Yang Ang \\ Michael Boddy \\ Yandi Liu \\ Bruce Sunderland \\ School of Pharmacy, Faculty of Health Sciences, Curtin University, Bentley, WA, Australia}

Video abstract

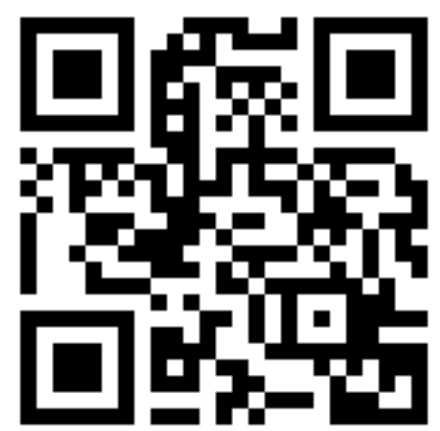

Point your SmartPhone at the code above. If you have a QR code reader the video abstract will appear. Or use

http://youtu.be/[Q2niZTUxPy
Correspondence: Zen Yang Ang Pharmacy Department, Oncology and Radiotherapy Institution, General Hospital of Kuala Lumpur, Kuala Lumpur, Malaysia Tel +60 I3 4889045 Email angzenyang@gmail.com

\begin{abstract}
Apomorphine in solution undergoes rapid autoxidation, producing greenish colored solutions, making it difficult to formulate as a stable pharmaceutical solution. To identify the optimum antioxidant agent/combination for apomorphine solution, a high performance liquid chromatography assay was used to study the stability of $50 \mu \mathrm{g} / \mathrm{mL}$ apomorphine $\mathrm{HCl}$ in $0.1 \%$ L-ascorbic acid (AA), $0.1 \%$ sodium metabisulfite (SMB), $0.1 \%$ EDTA, and in selected combinations at $25^{\circ} \mathrm{C}, 32^{\circ} \mathrm{C}$, and $37^{\circ} \mathrm{C}$ over a period of 14 days. The stability of apomorphine $\mathrm{HCl}(10 \mathrm{mg} / \mathrm{mL})$ in $0.1 \%$ AA solution and in $0.1 \%$ EDTA solution at $25^{\circ} \mathrm{C}$ and $37^{\circ} \mathrm{C}$ was also evaluated. Apomorphine $\mathrm{HCl}$ solution $(50 \mu \mathrm{g} / \mathrm{mL})$ in $0.1 \%$ AA plus $0.1 \% \mathrm{SMB}$ solution retained $99.7 \%$ (at $25^{\circ} \mathrm{C}$ ) and $95.9 \%$ (at $37^{\circ} \mathrm{C}$ ) of the initial concentration, as $0.1 \%$ AA plus SMB solution minimized the reactive oxygen content in solution which, in turn, reduced the oxidation rate of apomorphine $\mathrm{HCl}$, and there was no green coloration perceptible. Conversely, apomorphine $\mathrm{HCl}$ solution $\left(50 \mu \mathrm{g} / \mathrm{mL}\right.$ ) in $0.1 \% \mathrm{SMB}$ solution was unstable as only $0.53 \%$ (at $25^{\circ} \mathrm{C}$ ) and $0.06 \%$ (at $37^{\circ} \mathrm{C}$ ) of the initial concentration was retained after 14 days. All $10 \mathrm{mg} / \mathrm{mL}$ apomorphine $\mathrm{HCl}$ samples were stable in both studies. The initial concentration of apomorphine $\mathrm{HCl}$ solution markedly affected its rate of oxidation and discoloration. The addition of $0.1 \%$ AA to a current formulation of apomorphine $\mathrm{HCl}$ injection $\left(\right.$ Apomine $^{\circledR}$ ), which contains SMB as an antioxidant, was recommended as providing the most stable solution.
\end{abstract}

Keywords: apomorphine $\mathrm{HCl}$, oxidation, ascorbic acid, EDTA, sodium metabisulfite, HPLC

\section{Introduction}

Apomorphine is a basic derivative of morphine formed by its acid-catalyzed rearrangement. ${ }^{1,2}$ The chemical structure of apomorphine was reported ${ }^{3}$ more than a century after its first synthesis. ${ }^{1}$ It is a nonselective dopamine D1 and D2 receptor agonist, which is utilized as rescue medication in late stage Parkinson's disease. ${ }^{4}$ Nevertheless, the compound is well-known for its instability in aqueous solution. In the presence of light and air, it spontaneously forms oxoapomorphine producing a green coloration. Garrido et $\mathrm{al}^{5}$ studied the effect of $\mathrm{pH}$ on the anodic oxidation of apomorphine reporting a complex mechanism. In highly acidic media oxidation of catechol occurred, whereas above $\mathrm{pH} 3$ oxidation of the tertiary amine occurred. Above $\mathrm{pH} 6$, apomorphine in equilibrium with oxoapomorphine was oxidized. Recently, Udvardy et $\mathrm{al}^{1}$ suggested that below $\mathrm{pH} 7$ oxoapomorphine was the main degradation product with a quinone formed in alkaline media. At pH 6.4, they identified oxoapomorphine as the major degradation product with a phenanthrene as a minor (7\%) additional product, which was brownish yellow in color. An earlier study of the kinetics of this reaction showed a marked increase in the rate of oxidation in solution from $\mathrm{pH} 5.2$ to 6.8. ${ }^{6}$ Oxidative instability has become a barrier to the formulation of apomorphine, particularly in aqueous solution. ${ }^{1}$ 
Although the mechanism of autoxidation has been studied extensively in recent years, there are only a few studies that have investigated formulation factors aimed to improve the stability of apomorphine in aqueous solution. ${ }^{7-9}$ For example, Wilcox et $\mathrm{al}^{9}$ identified that the addition of ascorbic acid or sodium metabisulfite (SMB) to apomorphine solution, at room temperature, could only significantly delay oxidation of apomorphine in solution for less than 1-3 days. The author also established that a higher concentration of antioxidant and lower storage temperature could also significantly reduce the rate of oxidation of apomorphine. However, the study had an information gap where the sample solutions were not buffered and color changes of the sample solutions were not reported. The initial $\mathrm{pH}$ of the sample solution could affect the rate of degradation of apomorphine, and a color change in solution was an important indication of instability of the solution. Similarly, Ng Ying Kin et al ${ }^{7}$ found that $1 \mathrm{mg} / \mathrm{mL}$ apomorphine solution including $0.125 \%$ SMB was stable for more than 6 months at $4^{\circ} \mathrm{C}$. In addition, they reported that apomorphine solution was less stable at a lower concentration $(0.1 \mathrm{mg} / \mathrm{mL})$, despite the addition of SMB and storage at low temperature (ie, $4^{\circ} \mathrm{C}$ ), suggesting that SMB, which is a common antioxidant added to stabilize apomorphine injection formulation available on the market, might not be effective in preventing the degradation of apomorphine in solution.

Owing to limited data available from previous studies, a greater understanding of the oxidative degradation of apomorphine in the presence of antioxidants is necessary because it would contribute to improved formulations of apomorphine, which in turn increases the utilization and safety of this drug. This study aims to evaluate the stability of apomorphine $\mathrm{HCl}$ at standard and diluted concentrations in selected antioxidant systems in aqueous solution over a specific time period in order to identify the most effective antioxidant agent or antioxidant combination to minimize oxidation without any color change.

\section{Materials and methods}

\section{Chemicals and reagents}

Apomorphine $\mathrm{HCl}$, purchased from Professional Compounding Center of America ([purity - minimum 99\%] Houston, TX, USA), was used throughout the study. L-ascorbic acid (AA) was supplied by Thermo Fisher Scientific (Waltham, MA, USA), EDTA was obtained from Sigma-Aldrich Co. (St Louis, MO, USA), and SMB was purchased from Mallinckrodt Inc (Phillipsburg, NJ, USA). High performance liquid chromatography (HPLC) grade acetonitrile and methanol were obtained from SigmaAldrich Co. Water used throughout the study was prepared using a Milli-Q water purification system (EMD Millipore, Billerica, MA, USA).

\section{Synthesis and extraction of 6-methyl-5, 6-dihydro-4H-dibenzo[de,g]quinoline- 10 , I I-dione (oxoapomorphine)}

The procedures described by Abarca et a ${ }^{10}{ }^{10}$ were adapted for the production and extraction of oxoapomorphine. Briefly, $300 \mathrm{mg}$ of apomorphine $\mathrm{HCl}$ was dissolved in $50 \mathrm{~mL}$ of water and mixed with $5 \mathrm{~mL}$ of glacial acetic acid before the mixture was cooled in an ice bath for 2 hours. Subsequently, $40 \mathrm{~mL}$ of $0.1 \mathrm{M}$ aqueous solution of potassium dichromate was added and the mixture formed a dark green/blackish color. Dichloromethane was added to extract the mixture and the organic layer was bluish in color. The organic layer was neutralized with adequate sodium bicarbonate, dried with anhydrous sodium sulfate, filtered and evaporated with a Rotavapor ${ }^{\circledR}$ R-210 (Büchi Labortechnik AG, Flawil, Switzerland) before it was purified using thin layer chromatography (TLC) (refer to the section "TLC for Compound 1 extraction" for the details of TLC procedures), giving a blue solid Compound 1. Compound 1 was then subjected to liquid chromatography-mass spectrometry (LC-MS) (refer to the section "LC-MS for apomorphine $\mathrm{HCl}$ and Compound 1 analysis" for the details of LC-MS procedures) in order to identify its molecular weight.

\section{Instrumentation}

HPLC for assay validation and stability studies

The HPLC system consisted of a Agilent HPLC 1100 Series isocratic LC system (Agilent Technologies, Santa Clara, CA, USA) with diode array detector employed for assay validation and stability studies of apomorphine $\mathrm{HCl}$ solution. Separation of analytes was performed using an Apollo HPLC column (octadecylsilane-C18; $5 \mu \mathrm{M}$; pore size: $100 \AA$; length: $150 \mathrm{~mm}$; internal diameter $4.6 \mathrm{~mm}$; W.R. Grace \& Co., Columbia, MD, USA). The mobile phase consisted of $20 \%(\mathrm{v} / \mathrm{v})$ acetonitrile and $80 \%$ aqueous solution of $50 \mathrm{mM}$ orthophosphoric acid adjusted to $\mathrm{pH} 3.5$ with $5 \mathrm{M}$ sodium hydroxide. The HPLC was run with a flow rate of $1.0 \mathrm{~mL} / \mathrm{min}$ and UV detection wavelength of $280 \mathrm{~nm}$. The sample injection volume was $20 \mu \mathrm{L}$.

\section{TLC for Compound I extraction}

Alugram $^{\circledR}$ TLC sheets $(200 \times 200 \times 0.2 \mathrm{~mm}$; aluminum foil, silica gel 60 layer, with fluorescence indicator UV254) and 
ethyl acetate:hexane (9:1) mixture (mobile phase) were employed for the separation of apomorphine $\mathrm{HCl}$ and its degradants, Compound 1 (blue solid) was scraped off the TLC plates and dissolved in dichloromethane before analysis by LC-MS.

\section{LC-MS for apomorphine $\mathrm{HCl}$ and Compound I analysis}

LC-MS 2020, using a single quad mass spectrometer (Shimadzu, Kyoto, Japan) assay was developed for apomorphine $\mathrm{HCl}$ and Compound 1 at ambient temperature. Optimized mass spectra were acquired with an interface voltage of $4.5 \mathrm{kV}$, a detector voltage of $1 \mathrm{kV}$, a heat block temperature of $400^{\circ} \mathrm{C}$, and a desolvation gas temperature of $250^{\circ} \mathrm{C}$. Nitrogen was used as nebulizer gas at a flow rate of $1.5 \mathrm{~L} / \mathrm{min}$ and dry gas flow rate of $10 \mathrm{~L} / \mathrm{min}$.

\section{Assay validation}

\section{Specificity}

The specificity/stability indicating assay was modified from the procedures of earlier studies by Priston and Sewell ${ }^{11}$ and Ingram et al. ${ }^{12}$ There were two sets of samples consisting of $2.5 \mathrm{~mL}$ of $(100 \mu \mathrm{g} / \mathrm{mL})$ apomorphine $\mathrm{HCl}$ solutions which included: 1) $1 \mathrm{~mL}$ of $0.1 \mathrm{M} \mathrm{NaOH}$; 2) $1 \mathrm{~mL}$ of $0.1 \mathrm{M} \mathrm{HCl}$; 3) $1 \mathrm{~mL}$ of $6 \% \mathrm{H}_{2} \mathrm{O}_{2}$; and 4) $1 \mathrm{~mL}$ of water (as control), respectively. Each sample was diluted to $5 \mathrm{~mL}$ with water, sealed in a volumetric flask and incubated at $25^{\circ} \mathrm{C}$ (water bath), and analyzed after 10 and 60 minutes' exposure. Another two sets of samples were prepared and the study was repeated at $45^{\circ} \mathrm{C}$ (water bath). Mean residual concentration $(\mu \mathrm{g} / \mathrm{mL})$ and mean residual percentage of duplicate sets of samples were determined. Discoloration of the samples was also observed by the naked eye against a white background and recorded. The chromatograms were reviewed to ensure the analyte peak was pure. ${ }^{2}$

\section{Linearity}

Solution A ( $0.1 \%$ EDTA and $0.15 \%$ AA), as used by Ingram et $\mathrm{al},{ }^{12}$ was adapted for use in the preparation of standard solutions of apomorphine $\mathrm{HCl}(100 \mu \mathrm{g} / \mathrm{mL})$. The $100 \mu \mathrm{g} / \mathrm{mL}$ solution was then used to prepare a set of standard solutions with concentrations of $5,10,20,40,50,60$, and $80 \mu \mathrm{g} / \mathrm{mL}$. Each was analyzed in triplicate to obtain peak areas. Solution A was employed as the blank. Linearity of the standard plot was determined via least-squares regression analysis. The mean relative error of the observed versus calculated peak area and the mean value of relative standard deviations (RSDs) of the peak areas were calculated. ${ }^{2}$

\section{Range}

To assess the range of the method, the data from the standard curve were utilized to calculate the mean value of RSDs for each concentration involved in linearity assay. The accepted mean $\mathrm{RSD}$ was $<3 \%{ }^{2}$

\section{Precision - repeatability}

Quality control (QC) standards of $50 \mu \mathrm{g} / \mathrm{mL}$ were freshly prepared daily and analyzed to evaluate intra-day and interday precision of the assay. The intra-day precision was determined by analyzing ten samples from freshly prepared QC solutions while the inter-day precision was obtained by analyzing QC solutions (in quadruplicate), which were freshly prepared daily for 10 days. The mean value of observed concentration, standard deviation, RSD, and the mean value of retention times for the intra-day and inter-day QC standards were calculated. ${ }^{2}$

\section{Limit of detection and limit of quantitation}

The limit of detection (LOD) was defined as the value of standard deviation of $y$-intercept of the regression line $(\sigma) /$ slope (S) multiplied by 3.3 (ie, $3.3 \mathrm{\sigma} / \mathrm{s}$ ) while the limit of quantitation (LOQ) was defined as the value of standard deviation of $y$-intercept of the regression line $(\sigma) /$ Slope (S) multiplied by 10 (ie, $10 \sigma / \mathrm{s}$ ).,13,14 The LOD and LOQ were calculated from the data obtained from standard curve.

\section{Stability studies}

\section{Stability of apomorphine $\mathrm{HCl}$ in antioxidant solutions}

The stability of 1) apomorphine $\mathrm{HCl}$ solution without antioxidant; 2) apomorphine $\mathrm{HCl}$ in $0.1 \%$ AA solution; 3) apomorphine $\mathrm{HCl}$ in $0.1 \% \mathrm{SMB}$ solution; 4) apomorphine $\mathrm{HCl}$ in $0.1 \%$ EDTA solution; 5) apomorphine $\mathrm{HCl}$ in $0.1 \%$ AA plus $0.1 \%$ SMB solution; 6) apomorphine $\mathrm{HCl}$ in $0.1 \%$ AA plus $0.1 \%$ EDTA solution; and 7) apomorphine $\mathrm{HCl}$ in $0.1 \%$ SMB plus $0.1 \%$ EDTA solution were evaluated stored in sealed volumetric flasks at $25^{\circ} \mathrm{C}, 32^{\circ} \mathrm{C}$, and $37^{\circ} \mathrm{C}$, respectively in a water bath $\left( \pm 0.2^{\circ} \mathrm{C}\right)$ under typical laboratory conditions of light exposure. Solutions containing different antioxidants were adjusted to $\mathrm{pH} 4.0$ using $0.01 \mathrm{M}$ acetate buffer using a standardized $\mathrm{pH}$ meter (H8519N; Hanna Instruments, Woonsocket, RI, USA) before they were used in preparation of the sample solutions, which contained an initial concentration of $50 \mu \mathrm{g} / \mathrm{mL}$ apomorphine $\mathrm{HCl}$. All of the samples were prepared in duplicate and analyzed immediately after preparation and subsequently sampled after $0.5,1,2,4$, $8,24,48,72,96,168$, and 336 hours, respectively. Each of 
the sample solutions was analyzed twice by HPLC, and the mean reading for the particular sample was determined.

The color of the samples was also observed every 24 hours while the $\mathrm{pH}$ of the samples was measured at the end of the kinetic runs. In order to be defined as a stable apomorphine $\mathrm{HCl}$ solution in this study ("Stability of apomorphine $\mathrm{HCl}$ in antioxidant solutions" section), the following criteria needed to be fulfilled: 1 ) the mean residual concentration (\%) of both sets of samples, at the end of the study period, was within $95 \%-105 \%$ of the initial concentration of the samples and 2) no discoloration occurred in both sets of sample solutions that was visible to the naked eye, against a white background.

Stability of $10 \mathrm{mg} / \mathrm{mL}$ and $50 \mu \mathrm{g} / \mathrm{mL}$ (with and without acetate buffer) apomorphine $\mathrm{HCl}$ in $0.1 \%$ SMB solutions (purged with nitrogen)

To determine the effect of different initial concentrations of apomorphine $\mathrm{HCl}$ on the rate of degradation, two sets of $10 \mathrm{mg} / \mathrm{mL}$ apomorphine $\mathrm{HCl}$ solutions in $0.1 \% \mathrm{SMB}$ were buffered to $\mathrm{pH} 4.00$ using acetate buffer, while another two sets were prepared without buffer. Note that all of the samples described in this section were prepared using nitrogenbubbled (60 minutes) water and the headspace was flushed with nitrogen in order to imitate apomorphine $\mathrm{HCl}$ injection $\left(\right.$ Apomine $^{\circledR}$ ) which is available commercially. Another two $50 \mu \mathrm{g} / \mathrm{mL}$ apomorphine $\mathrm{HCl}$ in $0.1 \% \mathrm{SMB}$ solutions were prepared using the same method as above to imitate a diluted apomorphine $\mathrm{HCl}$ injection. All of the sample solutions were sealed in volumetric flasks and evaluated at $25^{\circ} \mathrm{C}$ in a water bath $\left( \pm 0.2^{\circ} \mathrm{C}\right)$ under typical laboratory conditions of light exposure. The stability of the sample solutions was analyzed immediately after preparation as well as after 24, 48, 72, and 168 hours. Each sample solution was analyzed twice by HPLC, and the mean reading for the particular sample was determined. The color and the $\mathrm{pH}$ of the sample solutions were observed and recorded after 168 hours. A stable apomorphine $\mathrm{HCl}$ solution occurred when the two criteria were fulfilled as defined in the "Stability of apomorphine $\mathrm{HCl}$ in antioxidant solutions" section.

Stability of apomorphine $\mathrm{HCl}$ solutions $(10 \mathrm{mg} / \mathrm{mL}$; without nitrogen purging) in $0.1 \% \mathrm{AA}$ solution and $0.1 \%$ EDTA solutions

Two sets of $10 \mathrm{mg} / \mathrm{mL}$ apomorphine $\mathrm{HCl}$ solution, $0.1 \% \mathrm{AA}$ solution (adjusted to $\mathrm{pH} 4.00$ using acetate buffer) and two sets of $10 \mathrm{mg} / \mathrm{mL}$ in $0.1 \%$ EDTA solution (adjusted to $\mathrm{pH} 4.00$ using acetate buffer) were prepared in sealed volumetric flasks and equilibrated at $25^{\circ} \mathrm{C}$ and $37^{\circ} \mathrm{C}$, respectively, in a water bath $\left( \pm 0.2^{\circ} \mathrm{C}\right)$ under typical laboratory conditions of light exposure for 72 hours. To be defined as a stable apomorphine $\mathrm{HCl}$ solution in this study (in this section), the particular sample had to fulfill the criteria as defined in "Stability of apomorphine $\mathrm{HCl}$ in antioxidant solutions" section.

\section{Results}

\section{LC-MS for apomorphine $\mathrm{HCl}$ and Compound I analysis}

As indicated in Figure 1A and B, retention times for apomorphine $\mathrm{HCl}$ and Compound 1 were 1.400 minutes and 2.279 minutes, respectively, while $\mathrm{m} / \mathrm{z}$ for apomorphine $\mathrm{HCl}$ and Compound 1 were found to be 268 and 264, respectively.

\section{Assay validation Specificity}

The data from specificity/stability indicating assay (Table 1) show that apomorphine $\mathrm{HCl}$ degraded rapidly in $0.02 \mathrm{M}$ sodium hydroxide and produced a brown colored solution. Addition of hydrogen peroxide also significantly increased the degradation rate although the rate was slower compared to forced degradation in sodium hydroxide. Apomorphine $\mathrm{HCl}$ solutions showed similar stability in $0.02 \mathrm{M}$ hydrochloric acid compared to the control solution (apomorphine $\mathrm{HCl}$ in water).

As shown in Figure 2A-D, the peak of apomorphine $\mathrm{HCl}$ and the peaks of its degradants could be distinguished clearly in the chromatograms produced from the forced degradation of apomorphine $\mathrm{HCl}$. This indicated that the conditions employed in this study could separate apomorphine $\mathrm{HCl}$ from its degradants.

\section{Linearity}

For a concentration range of $5-80 \mu \mathrm{g} / \mathrm{mL}$, the standard curve of apomorphine $\mathrm{HCl}$ calibration solutions in diluent $\mathrm{A}$ was linear $\left(y=61.613 x+11.672 ; R^{2}=0.9998 ; \mathrm{n}=7\right)$. The mean relative error of the observed versus calculated peak areas was $0.80 \%$, while the mean RSD of the observed peak areas was $0.39 \%$.

\section{Range}

The mean value of RSDs for each concentration of the samples involved in the linearity assay was $0.39 \%$, which was less than $3 \%$.

\section{Precision - repeatability}

The mean ( \pm standard deviation) and RSD for observed intra-day concentration $(n=10)$ of the QC standards were 
A
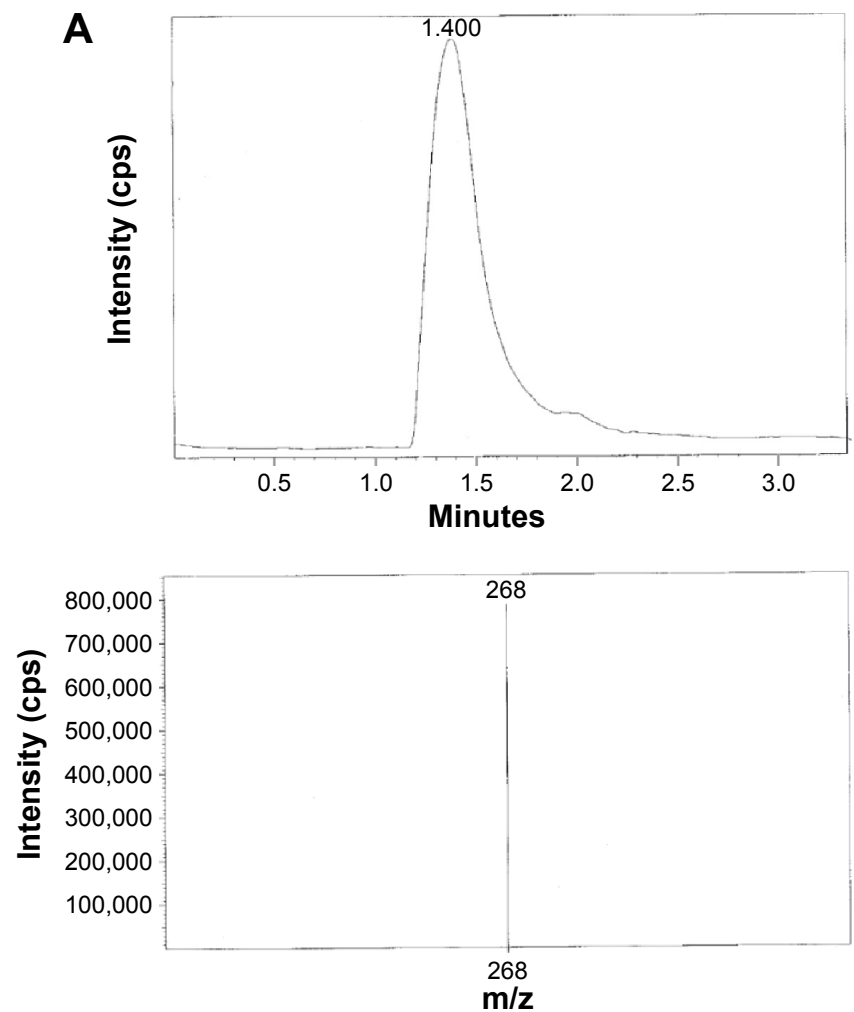

B
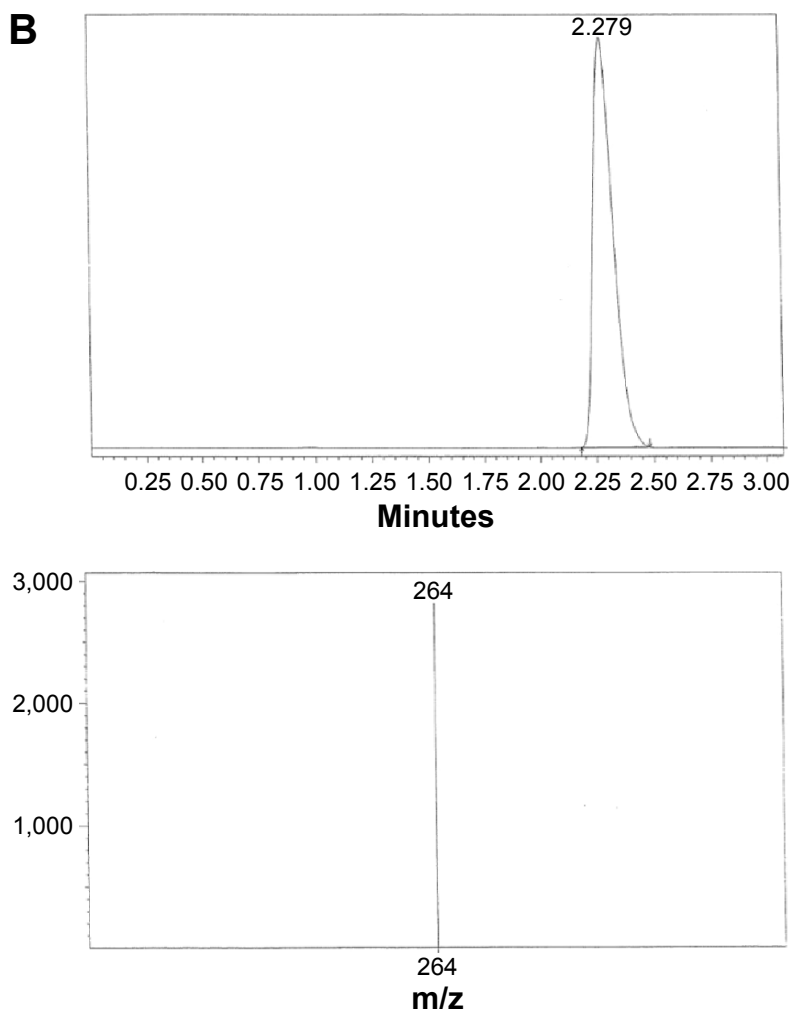

Figure I Chromatographs and mass spectra produced by liquid chromatography-mass spectrometry. Notes: (A) apomorphine $\mathrm{HCl}$; (B) Compound I.

Table I Mean residual concentration $(\mu \mathrm{g} / \mathrm{mL})$ of apomorphine $\mathrm{HCl}$ solutions, mean residual concentration (\%), and color observed after specificity assay/forced degradation

\begin{tabular}{|c|c|c|c|c|c|}
\hline Reagent & $\begin{array}{l}\text { Temperature } \\
\left({ }^{\circ} \mathrm{C}\right)\end{array}$ & $\begin{array}{l}\text { Time } \\
(\min )\end{array}$ & $\begin{array}{l}\text { Mean residual apomorphine } \\
\mathrm{HCl} \text { concentration }(\mu \mathrm{g} / \mathrm{mL})\end{array}$ & $\begin{array}{l}\text { Mean residual apomorphine } \\
\mathrm{HCl} \text { concentration (\%) }\end{array}$ & $\begin{array}{l}\text { Observed } \\
\text { color changes }\end{array}$ \\
\hline \multirow[t]{6}{*}{ Water } & 25 & 0 & 50.0 & 100.0 & Colorless \\
\hline & & 10 & 49.9 & 99.7 & Very light green \\
\hline & & 60 & 48.5 & 97.1 & Light green \\
\hline & 45 & 0 & 50.0 & 100.0 & Colorless \\
\hline & & 10 & 49.7 & 99.4 & Light green \\
\hline & & 60 & 47.5 & 95.0 & Green \\
\hline \multirow[t]{6}{*}{$0.02 \mathrm{M} \mathrm{NaOH}$} & 25 & 0 & 50.0 & 100.0 & Colorless \\
\hline & & 10 & 0 & 0 & Brown \\
\hline & & 60 & 0 & 0 & Brown \\
\hline & 45 & 0 & 50.0 & 100.0 & Colorless \\
\hline & & 10 & 0 & 0 & Brown \\
\hline & & 60 & 0 & 0 & Brown \\
\hline \multirow[t]{6}{*}{$0.02 \mathrm{M} \mathrm{HCl}$} & 25 & 0 & 50.0 & 100.0 & Colorless \\
\hline & & 10 & 50.0 & 100.0 & Colorless \\
\hline & & 60 & 49.7 & 99.4 & Colorless \\
\hline & 45 & 0 & 50.0 & 100.0 & Colorless \\
\hline & & 10 & 49.8 & 99.6 & Colorless \\
\hline & & 60 & 49.4 & 98.8 & Colorless \\
\hline \multirow{6}{*}{ I. $2 \% \mathrm{H}_{2} \mathrm{O}_{2}$} & 25 & 0 & 50.0 & 100.0 & Colorless \\
\hline & & 10 & 43.8 & 87.6 & Colorless \\
\hline & & 60 & 26.2 & 52.5 & Colorless \\
\hline & 45 & 0 & 50.0 & 100.0 & Colorless \\
\hline & & 10 & 17.8 & 35.5 & Colorless \\
\hline & & 60 & 4.7 & 9.3 & Colorless \\
\hline
\end{tabular}

Note: Apomorphine $\mathrm{HCl}$ sample solutions for each assay were prepared in duplicate $(\mathrm{n}=2)$.

Abbreviation: min, minutes. 

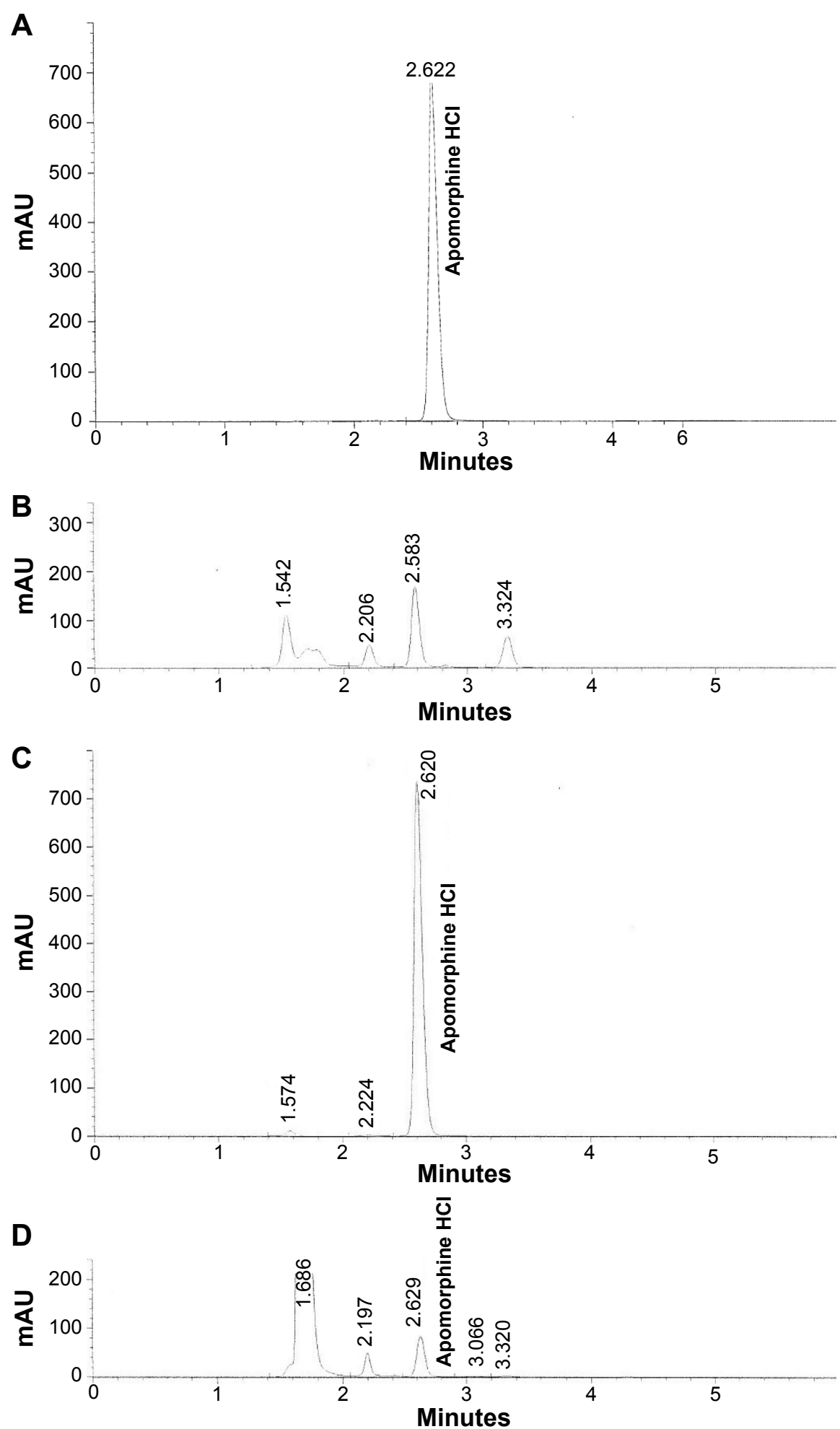

Figure 2 Chromatographs of specificity assay/forced degradation of apomorphine $\mathrm{HCl}$.

Notes: (A) Apomorphine $\mathrm{HCl}$ solution (without additive) $\left(60\right.$ minutes at $\left.45^{\circ} \mathrm{C}\right)$; (B) reaction of apomorphine $\mathrm{HCl}$ in $0.02 \mathrm{M} \mathrm{NaOH}\left(60\right.$ minutes at $\left.45^{\circ} \mathrm{C}\right)$, no apomorphine $\mathrm{HCl}$ peak detected in the forced degradation by $0.02 \mathrm{M} \mathrm{NaOH}$. (C) reaction of apomorphine $\mathrm{HCl}$ with $0.02 \mathrm{M} \mathrm{HCl}\left(60\right.$ minutes at $\left.45^{\circ} \mathrm{C}\right)$; and $(\mathbf{D})$ reaction of apomorphine $\mathrm{HCl}$ in $1.2 \% \mathrm{H}_{2} \mathrm{O}_{2}\left(60\right.$ minutes at $\left.45^{\circ} \mathrm{C}\right)$. The peak labels illustrate the retention times.

$50.3 \pm 0.5 \mu \mathrm{g} / \mathrm{mL}$ of apomorphine $\mathrm{HCl}$ with an RSD of $0.97 \%$. The mean ( \pm standard deviation) and RSD for observed inter-day concentration $(n=10)$ of the QC standards were $51.0 \pm 0.9 \mu \mathrm{g} / \mathrm{mL}$ with an RSD of $1.79 \%$.
The mean ( \pm standard deviation) and RSD for observed intra-day and inter-day retention times $(n=10)$ of the QC standards were $2.63 \pm 0.01$ minutes with an RSD of $0.33 \%$ and $2.63 \pm 0.01$ minutes with an RSD of $0.21 \%$. The RSDs 
for intra-day and inter-day concentration and retention times of the QC standards were within the acceptable range of $\leq 2 \%$. ${ }^{15}$

\section{LOD and LOQ}

The LOD and LOQ values were $1.05 \mu \mathrm{g} / \mathrm{mL}$ and $3.18 \mu \mathrm{g} / \mathrm{mL}$, respectively.

\section{Stability studies}

Studies on the stability of apomorphine $\mathrm{HCl}$ in antioxidant solutions

The natural logarithm (ln) of mean residual concentrations (\%) of apomorphine $\mathrm{HCl}$ solutions in different antioxidant solutions against time at $25^{\circ} \mathrm{C}, 32^{\circ} \mathrm{C}$, and $37^{\circ} \mathrm{C}$ is illustrated in Figures 3-5.

Figures 3-5 indicate that the rates of oxidation of apomorphine $\mathrm{HCl}$ in the sample solutions increased with temperature. Table 2 shows that all sample solutions changed color at the end of the study, with the exception of those in $0.1 \%$ AA plus $0.1 \%$ SMB and sample solutions in $0.1 \% \mathrm{SMB}$ plus $0.1 \%$ EDTA (at $25^{\circ} \mathrm{C}$ only) as well as sample solutions in $0.1 \%$ AA plus $0.1 \%$ EDTA (at $25^{\circ} \mathrm{C}$ only) which remained colorless. The results also indicated that the discoloration of sample solutions intensified over the study time and with increased temperature. The studies in $0.1 \%$ AA did not follow first-order kinetics over the 336 hours of testing. Overall it was only the apomorphine in $0.1 \%$ AA plus $0.1 \%$ SMB solution at $\mathrm{pH} 4.00$ that retained $>95 \%$ of the initial concentration and remained colorless over the duration of the study.

It was also found that the $\mathrm{pH}$ of most of the sample solutions after 336 hours did not markedly change from the initial $\mathrm{pH}$ of 4.00 . The $\mathrm{pH}$ readings of all samples indicated the $\mathrm{pH}$ remained confined within a tight range $(\mathrm{pH} 4.00 \pm 0.20)$ with the exception of apomorphine $\mathrm{HCl}$ in $0.1 \% \mathrm{SMB}$ sample solutions at $32^{\circ} \mathrm{C}$ and $37^{\circ} \mathrm{C}$, as well as apomorphine $\mathrm{HCl}$ in $0.1 \%$ AA plus $0.1 \% \mathrm{SMB}$ sample solutions (at $37^{\circ} \mathrm{C}$ ).

Although apomorphine $\mathrm{HCl}$ in $0.1 \%$ EDTA (ie, $99.20 \%$ at $25^{\circ} \mathrm{C}$ ) fulfilled the first criterion of stability, it did not fulfill the second criterion as it turned light blue at the end of the study. Therefore, only apomorphine $\mathrm{HCl}$ in $0.1 \%$

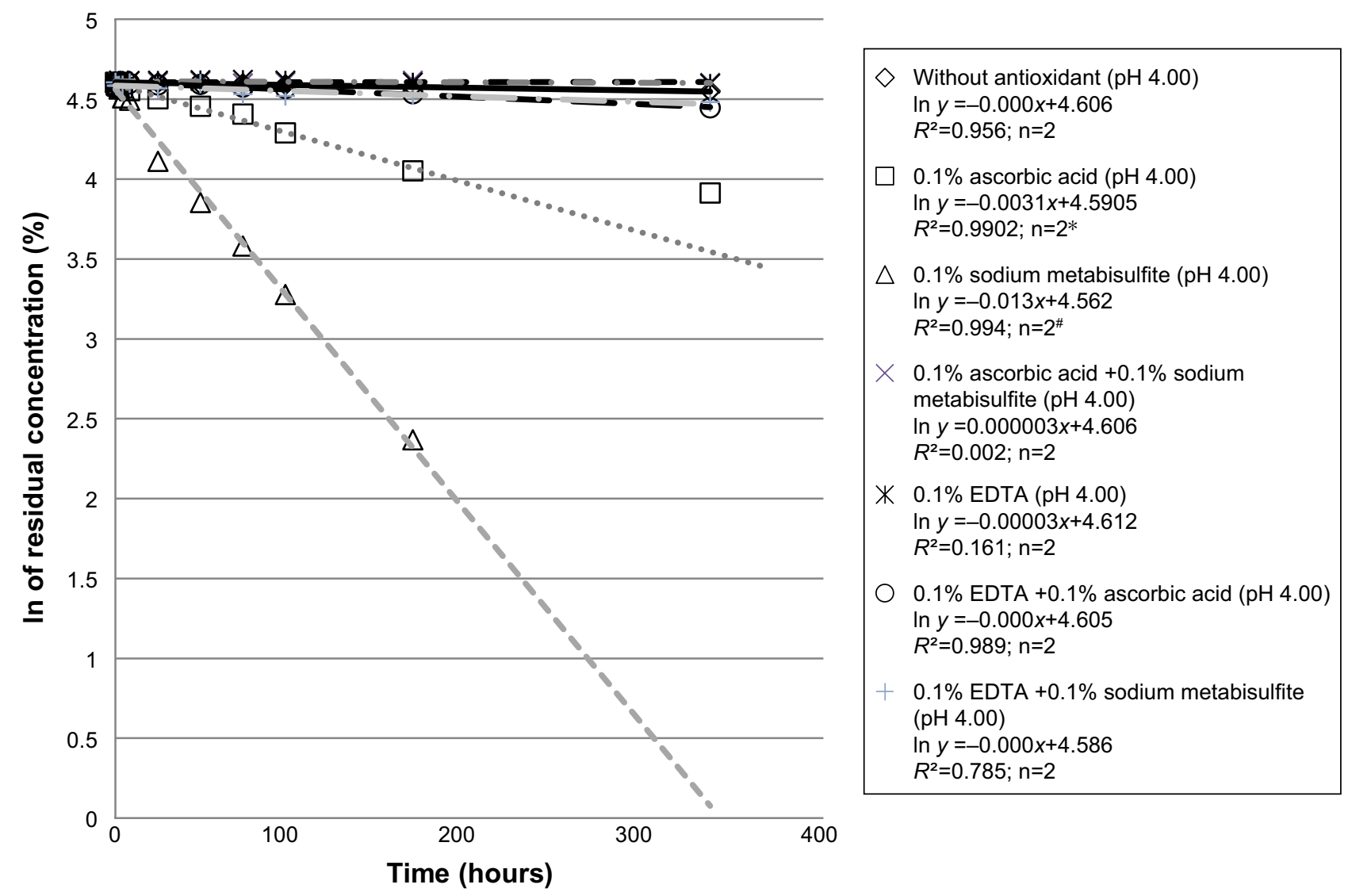

Figure $3 \mathrm{Natural}$ logarithm (In) of mean residual concentration (\%) of apomorphine $\mathrm{HCl}$ solutions $(50 \mu \mathrm{g} / \mathrm{mL})$ in different antioxidant solutions over 336 hours at $25^{\circ} \mathrm{C}$. Notes: Apomorphine $\mathrm{HCl}$ sample solutions for each assay were prepared in duplicate $(\mathrm{n}=2)$. * Linear trend line of $0.1 \% \mathrm{AA}$ solution $(\mathrm{pH} 4.00)$ did not include data points at 96 hours, 168 hours, and 336 hours as the rate of reaction decreased significantly after 96 hours. \#Value from apomorphine $\mathrm{HCl}$ in $0.1 \% \mathrm{SMB}$ solution (pH 4.00 ) at 336 hours was not included as the value was zero (or approximately zero).

Abbreviations: AA, L-ascorbic acid; SMB, sodium metabisulfite. 


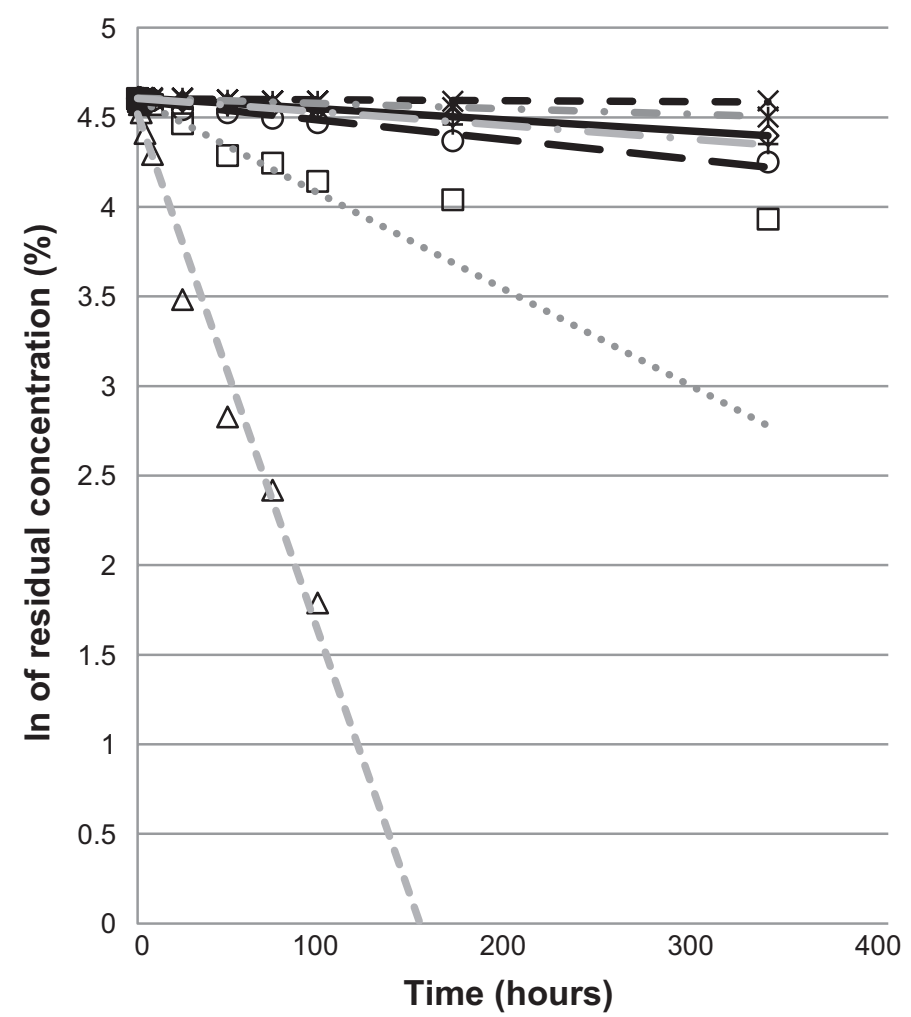

$\diamond$ Without antioxidant $(\mathrm{pH} 4.00)$

In $y=-0.000 x+4.608$

$R^{2}=0.997 ; \mathrm{n}=2$

$\square 0.1 \%$ ascorbic acid $(\mathrm{pH} 4.00)$

In $y=-0.0054 x+4.5998$

$R^{2}=0.9708 ; \mathrm{n}=2 *$

$\triangle 0.1 \%$ sodium metabisulfite $(\mathrm{pH} 4.00)$

In $y=-0.03 x+4.518$

$R^{2}=0.978 ; \mathrm{n}=2^{\#}$

$\times 0.1 \%$ ascorbic acid $+0.1 \%$ sodium metabisulfite (pH 4.00)

In $y=-0.00005 x+4.603$

$R^{2}=0.507 ; \mathrm{n}=2$

* $0.1 \%$ EDTA (pH 4.00)

In $y=-0.000 x+4.607$

$R^{2}=0.964 ; \mathrm{n}=2$

$0.1 \%$ EDTA $+0.1 \%$ ascorbic acid $(\mathrm{pH} 4.00)$

In $y=-0.001 x+4.591$

$R^{2}=0.966 ; \mathrm{n}=2$

$+0.1 \%$ EDTA $+0.1 \%$ sodium metabisulfite $(\mathrm{pH} 4.00)$

In $y=-0.000 x+4.604$

$R^{2}=0.990 ; \mathrm{n}=2$

Figure $4 \mathrm{Natural}$ logarithm (In) of mean residual concentration (\%) of apomorphine $\mathrm{HCl}$ solutions $(50 \mu \mathrm{g} / \mathrm{mL})$ in different antioxidant solutions over $336 \mathrm{hours}$ at $32^{\circ} \mathrm{C}$ Notes: Apomorphine $\mathrm{HCl}$ sample solutions for each assay were prepared in duplicate $(\mathrm{n}=2)$. * Linear trend line of $0.1 \% \mathrm{AA}$ solution ( $\mathrm{pH} 4.00)$ did not include data points at 96 hours, 168 hours, and 336 hours as the rate of reaction decreased significantly after 96 hours. \#Values from apomorphine $\mathrm{HCl}$ in $0.1 \% \mathrm{SMB}$ solution (pH 4.00 ) at I68 and 336 hours were not included as the values were zero (or approximately zero).

Abbreviations: AA, L-ascorbic acid; SMB, sodium metabisulfite.

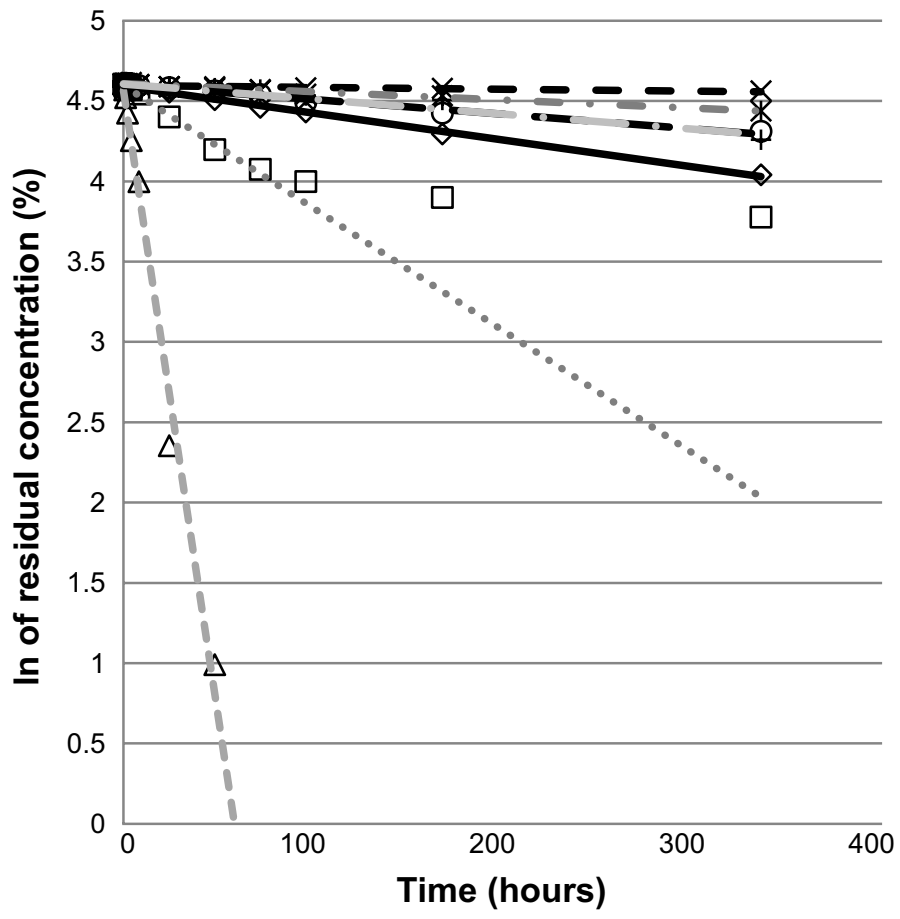

$\diamond \quad$ Without antioxidant $(\mathrm{pH} 4.00)$

In $y=-0.001 x+4.592$

$R^{2}=0.997 ; \mathrm{n}=2$

$\square \quad 0.1 \%$ ascorbic acid $(\mathrm{pH} 4.00)$

In $y=-0.0076 x+4.5974$

$R^{2}=0.993 ; \mathrm{n}=2^{*}$

$\triangle 0.1 \%$ sodium metabisulfite $(\mathrm{pH} 4.00)$

In $y=-0.077 x+4.565$

$R^{2}=0.987 ; \mathrm{n}=2^{\#}$

$\times \quad 0.1 \%$ ascorbic acid $+0.1 \%$ sodium metabisulfite $(\mathrm{pH} 4.00)$

In $y=-0.000 x+4.597$

$R^{2}=0.659 ; \mathrm{n}=2$

$* \quad 0.1 \%$ EDTA (pH 4.00)

In $y=-0.000 x+4.607$

$R^{2}=0.981 ; \mathrm{n}=2$

O $\quad 0.1 \%$ EDTA $+0.1 \%$ ascorbic acid $(\mathrm{pH} 4.00)$

In $y=-0.000 x+4.601$

$R^{2}=0.983 ; \mathrm{n}=2$

$+0.1 \%$ EDTA $+0.1 \%$ sodium metabisulfite $(\mathrm{pH} \mathrm{4.00)}$

In $y=-0.000 x+4.605$

$R^{2}=0.95 ; \mathrm{n}=2$

Figure 5 Natural logarithm (In) of mean residual concentration (\%) of apomorphine $\mathrm{HCl}$ solutions $(50 \mu \mathrm{g} / \mathrm{mL})$ in different antioxidant solutions over 336 hours at $37^{\circ} \mathrm{C}$ Notes: Apomorphine $\mathrm{HCl}$ sample solutions for each assay were prepared in duplicate $(\mathrm{n}=2)$. *Linear trend line of $0.1 \% \mathrm{AA}$ solution (pH 4.00) did not include data points at 96 hours, 168 hours, and 336 hours as the rate of reaction decreased significantly after 96 hours. " Values from apomorphine $\mathrm{HCl}$ in $0.1 \% \mathrm{SMB}$ solution (pH 4.00$)$ at $72,96,168$, and 336 hours were not included as the values were zero (or approximately zero).

Abbreviations: AA, L-ascorbic acid; SMB, sodium metabisulfite. 
Table 2 Mean residual concentration (\%), color changes, and final $\mathrm{pH}$ values of apomorphine $\mathrm{HCl}$ sample solutions (which were colorless initially) after 336 hours

\begin{tabular}{|c|c|c|c|c|c|c|}
\hline $\begin{array}{l}\text { Apomorphine } \mathrm{HCl} \text { in } \\
\text { different solutions }\end{array}$ & $\begin{array}{l}\text { Experimental } \\
\text { temperature } \\
\left({ }^{\circ} \mathrm{C}\right)\end{array}$ & $\begin{array}{l}\text { Mean residual } \\
\text { concentration } \\
\text { at } 336 \text { hours (\%)* }\end{array}$ & $\begin{array}{l}\text { Color of } \\
\text { solution at } \\
336 \text { hours }\end{array}$ & $\begin{array}{l}\text { Time (day) } \\
\text { when color } \\
\text { change was } \\
\text { first observed }\end{array}$ & $\begin{array}{l}\text { Period of time } \\
\text { where mean residual } \\
\text { concentration was } \\
\text { within } 95 \%-105 \% \text { (hours) }\end{array}$ & $\begin{array}{l}\text { pH at } \\
336 \text { hours }\end{array}$ \\
\hline \multirow[t]{3}{*}{$0.1 \% \mathrm{AA}$} & 25 & 50.02 & Copper & 2 & 10 & 3.88 \\
\hline & 32 & 50.98 & Copper & 1 & 10 & 3.93 \\
\hline & 37 & 43.69 & Copper & 1 & 5 & 3.93 \\
\hline \multirow[t]{3}{*}{$0.1 \%$ SMB } & 25 & 0.53 & Very light yellow & II & $<5$ & 3.84 \\
\hline & 32 & 0.05 & Very light yellow & 5 & $<5$ & 3.63 \\
\hline & 37 & 0.06 & Light yellow & 3 & $<3$ & 3.45 \\
\hline \multirow[t]{3}{*}{$0.1 \%$ EDTA } & 25 & 99.20 & Light blue & 4 & $>336$ & 4.02 \\
\hline & 32 & 90.17 & Light blue & 2 & 200 & 3.98 \\
\hline & 37 & 84.58 & Emerald & 0 & 120 & 3.92 \\
\hline \multirow[t]{3}{*}{$0.1 \% \mathrm{AA}+0.1 \% \mathrm{SMB}$} & 25 & 99.73 & Colorless & - & $>336$ & 3.94 \\
\hline & 32 & 98.66 & Colorless & - & $>336$ & 3.81 \\
\hline & 37 & 95.86 & Colorless & - & $>336$ & 3.64 \\
\hline \multirow[t]{3}{*}{$0.1 \%$ AA $+0.1 \%$ EDTA } & 25 & 85.26 & Colorless & - & 130 & 3.91 \\
\hline & 32 & 70.12 & Yellow & 4 & 45 & 3.98 \\
\hline & 37 & 74.51 & Yellow & 4 & 50 & 3.91 \\
\hline \multirow[t]{3}{*}{$0.1 \%$ SMB +0. $1 \%$ EDTA } & 25 & 88.37 & Colorless & - & 95 & 4.02 \\
\hline & 32 & 77.53 & Colorless & - & 70 & 3.90 \\
\hline & 37 & 70.72 & Colorless & - & 50 & 3.91 \\
\hline \multirow[t]{3}{*}{ Water (without antioxidant) } & 25 & 94.68 & Light blue & 2 & 310 & 4.08 \\
\hline & 32 & 81.23 & Light blue & 1 & 100 & 3.87 \\
\hline & 37 & 56.84 & Emerald & 0 & 25 & 3.96 \\
\hline
\end{tabular}

Notes: Apomorphine $\mathrm{HCl}$ sample solutions for each assay were prepared in duplicate $(\mathrm{n}=2)$. The initial concentration of sample solutions was $50 \mu \mathrm{g} / \mathrm{mL}$. $*$ The acceptable limit of mean residual concentration at the end of period of stability study is between $95 \%$ to $105 \%$. "Initial $\mathrm{pH}$ was buffered by acetate buffer to $\mathrm{pH} 4$.

Abbreviations: AA, L-ascorbic acid; SMB, sodium metabisulfite.

$\mathrm{AA}+0.1 \%$ SMB was considered stable when compared with other antioxidant systems in this study. None of the apomorphine $\mathrm{HCl}$ solutions were stable when stored at $37^{\circ} \mathrm{C}$ at the end of the study period except apomorphine $\mathrm{HCl}$ in $0.1 \% \mathrm{AA}+0.1 \% \mathrm{SMB}$.

On the other hand, apomorphine $\mathrm{HCl}$ was found to be very unstable in only $0.1 \%$ SMB solutions where the apomorphine $\mathrm{HCl}$ in all experimental temperatures was essentially undetected at the end of the study, followed by apomorphine $\mathrm{HCl}$ in $0.1 \%$ AA solutions where the final concentration was approximately one-half of its initial concentration.

Studies on stability of $10 \mathrm{mg} / \mathrm{mL}$ and $50 \mu \mathrm{g} / \mathrm{mL}$ (with acetate buffer and without buffer) apomorphine $\mathrm{HCl}$ in $0.1 \% \mathrm{SMB}$ solutions purged with nitrogen

The color of all sample solutions remained unchanged after 168 hours. Table 3 and Figure 6 illustrate that both $10 \mathrm{mg} / \mathrm{mL}$ apomorphine $\mathrm{HCl}$ in $0.1 \% \mathrm{SMB}$ solutions purged with nitrogen (ie, imitated apomorphine $\mathrm{HCl}$ injection) with buffer and without buffer, retained approximately $100 \%$ of their initial concentration. On the other hand, $50 \mu \mathrm{g} / \mathrm{mL}$ apomorphine $\mathrm{HCl}$ in $0.1 \% \mathrm{SMB}$ solution with buffer (ie, imitated diluted apomorphine $\mathrm{HCl}$ injection) lost approximately $80 \%$ of the initial concentration while the $50 \mu \mathrm{g} / \mathrm{mL}$ sample solution without buffer retained approximately $60 \%$ of the initial concentration. Thus, the $10 \mathrm{mg} / \mathrm{mL}$ apomorphine $\mathrm{HCl}$ solutions (both with buffer and without buffer and nitrogen purged) were considered stable as the remaining concentrations were within $95 \%-105 \%$ of the initial concentration, and there was no discoloration after 168 hours. In contrast to the $10 \mathrm{mg} / \mathrm{mL}$ sample solutions, both $50 \mu \mathrm{g} / \mathrm{mL}$ sample solutions (nitrogen purged) with buffer and without buffer were defined as unstable.

Stability of apomorphine $\mathrm{HCl}$ solutions $(10 \mathrm{mg} / \mathrm{mL})$ in $0.1 \% \mathrm{AA}$ solution and $0.1 \%$ EDTA solutions (without nitrogen purging)

Table 4 shows that the mean residual concentration (\%) of apomorphine $\mathrm{HCl}$ in $0.1 \%$ AA solution $(10 \mathrm{mg} / \mathrm{mL})$ and apomorphine $\mathrm{HCl}$ in $0.1 \%$ EDTA solution $(10 \mathrm{mg} / \mathrm{mL})$ after 72 hours were within $95 \%-105 \%$ of the initial concentration at $25^{\circ} \mathrm{C}$ and $37^{\circ} \mathrm{C}$. None of the $10 \mathrm{mg} / \mathrm{mL}$ sample solutions changed in color at the end of the study period and therefore were considered stable as defined by the section "Stability of apomorphine $\mathrm{HCl}$ in antioxidant solutions". 
Table 3 Mean residual concentration $(\mu \mathrm{g} / \mathrm{mL})$, mean residual concentration (\%), color changes, initial $\mathrm{pH}$ and post-study $\mathrm{pH}$ of $10 \mathrm{mg} / \mathrm{mL}$ and $50 \mu \mathrm{g} / \mathrm{mL}$ apomorphine $\mathrm{HCl}$ solutions (purged with nitrogen) after 168 hours

\begin{tabular}{|c|c|c|c|c|c|c|}
\hline Experimental conditions & $\begin{array}{l}\text { Experimental } \\
\text { temperature } \\
\left({ }^{\circ} \mathrm{C}\right)\end{array}$ & $\begin{array}{l}\text { Mean residual } \\
\text { concentration } \\
(\%) \text { at } 168 \text { hours* }\end{array}$ & $\begin{array}{l}\text { Mean residual } \\
\text { concentration } \\
\text { at } 168 \text { hours }\end{array}$ & $\begin{array}{l}\text { Color of } \\
\text { solution at } \\
168 \text { hours }\end{array}$ & Initial pH & $\begin{array}{l}\mathrm{pH} \text { at } \\
168 \text { hours }\end{array}$ \\
\hline $\begin{array}{l}\text { Apomorphine } \mathrm{HCl}(10 \mathrm{mg} / \mathrm{mL}) \text { in } \\
0.1 \% \mathrm{SMB} \text { (buffered by acetate buffer) }\end{array}$ & 25 & 102.2 & $10.2 \mathrm{mg} / \mathrm{mL}$ & Colorless & 4.00 & 3.81 \\
\hline $\begin{array}{l}\text { Apomorphine } \mathrm{HCl}(10 \mathrm{mg} / \mathrm{mL}) \text { in } \\
0.1 \% \mathrm{SMB} \text { (no buffer) }\end{array}$ & 25 & 100.0 & $10 \mathrm{mg} / \mathrm{mL}$ & Colorless & 2.71 & 2.27 \\
\hline $\begin{array}{l}\text { Apomorphine } \mathrm{HCl}(50 \mu \mathrm{g} / \mathrm{mL}) \text { in } \\
0.1 \% \mathrm{SMB} \text { (buffered by acetate buffer) }\end{array}$ & 25 & 20.8 & $10.4 \mu \mathrm{g} / \mathrm{mL}$ & Colorless & 4.00 & 3.88 \\
\hline $\begin{array}{l}\text { Apomorphine } \mathrm{HCl}(50 \mu \mathrm{g} / \mathrm{mL}) \text { in } \\
0.1 \% \mathrm{SMB} \text { (no buffer) }\end{array}$ & 25 & 41.8 & $20.9 \mu \mathrm{g} / \mathrm{mL}$ & Colorless & 3.44 & 3.04 \\
\hline
\end{tabular}

Notes: Apomorphine $\mathrm{HCl}$ sample solutions for each assay were prepared in duplicate $(\mathrm{n}=2)$. *The acceptable limit of mean residual concentration at the end of period of stability study is between $95 \%$ and $105 \%$.

Abbreviation: SMB, sodium metabisulfite.

\section{Discussion}

This study has investigated the influence of selected antioxidant systems on the stability of apomorphine in solution in order to select the optimum antioxidant system. Two concentrations were selected, which were the commonly formulated one of $10 \mathrm{mg} / \mathrm{mL}$ and a diluted one which could be given as an infusion and represents a more difficult concentration to preserve. Of all antioxidant systems investigated in the section "Stability of apomorphine $\mathrm{HCl}$ in antioxidant solutions", $0.1 \% \mathrm{AA}+0.1 \% \mathrm{SMB}$ solution provided the only environment where, over the temperature range of $25^{\circ} \mathrm{C}$ to $37^{\circ} \mathrm{C}$, the concentration of apomorphine was $>95 \%$ and the solution remained colorless for $50 \mu \mathrm{g} / \mathrm{mL}$ apomorphine $\mathrm{HCl}$ solution. On the other hand, apomorphine $\mathrm{HCl}$ appeared to

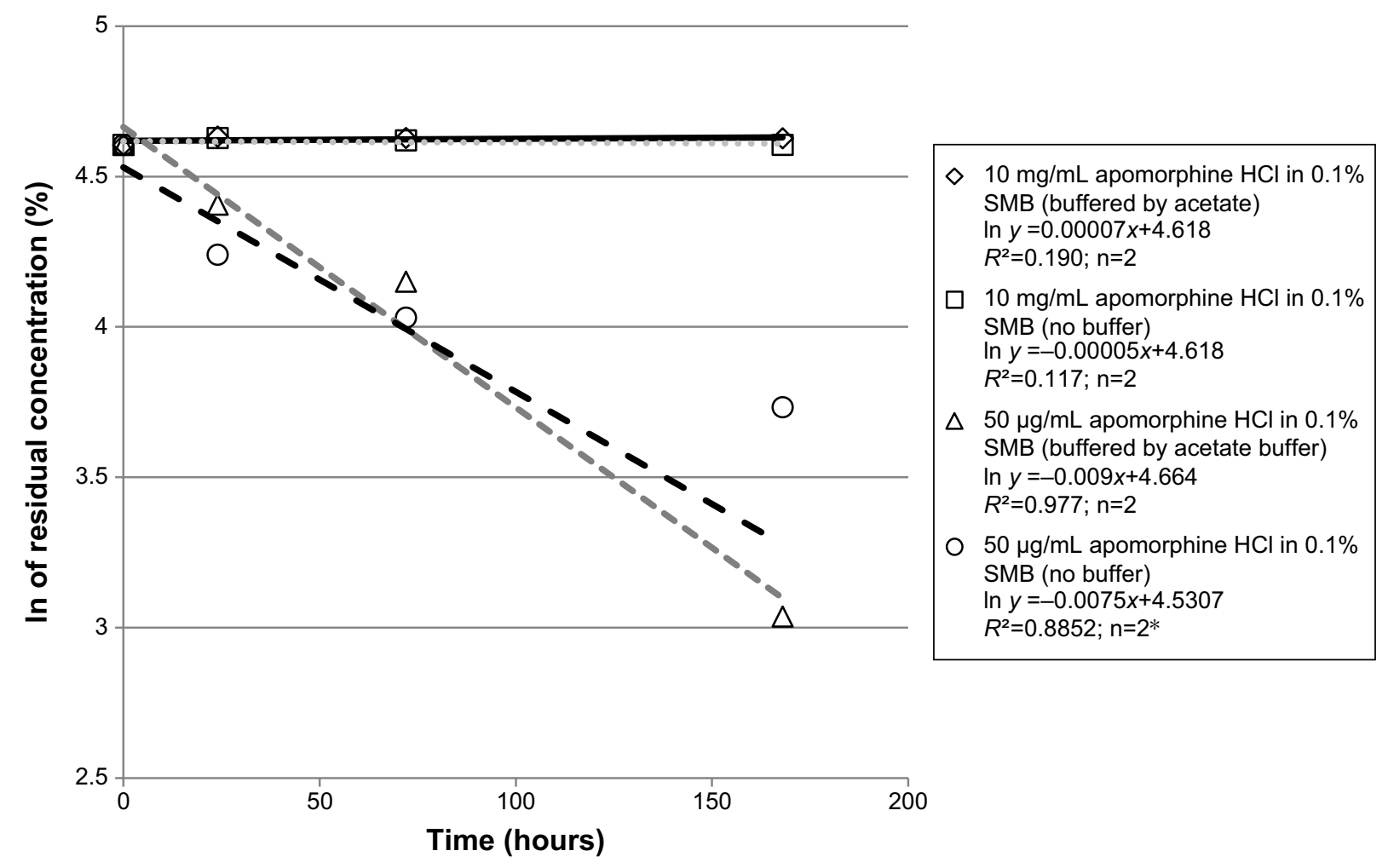

Figure 6 Natural logarithm (In) of mean residual concentration (\%) of $10 \mathrm{mg} / \mathrm{mL}$ and $50 \mu \mathrm{g} / \mathrm{mL}$ apomorphine $\mathrm{HCl}$ in $0.1 \%$ SMB solutions (with and without buffer; both purged with nitrogen) over 168 hours at $25^{\circ} \mathrm{C}$.

Notes: Apomorphine $\mathrm{HCl}$ sample solutions for each assay were prepared in duplicate $(\mathrm{n}=2)$. * Linear trend line of $50 \mu \mathrm{g} / \mathrm{mL}$ apomorphine $\mathrm{HCl}$ in $0.1 \% \mathrm{SMB}$ solutions (without buffer) did not include data points at 168 hours as the rate of reaction decreased significantly after 72 hours.

Abbreviation: SMB, sodium metabisulfite. 
Table 4 Mean residual concentration (\%), mean residual concentration $(\mathrm{mg} / \mathrm{mL})$ and color observation, initial $\mathrm{pH}$ and post-study $\mathrm{pH}$ of $10 \mathrm{mg} / \mathrm{mL}$ apomorphine $\mathrm{HCl}$ (without nitrogen purging) in $0.1 \%$ AA solution and $10 \mathrm{mg} / \mathrm{mL}$ apomorphine $\mathrm{HCl}$ in $0.1 \%$ EDTA solution at $25^{\circ} \mathrm{C}$ after 72 hours

\begin{tabular}{lllllll}
\hline $\begin{array}{l}\text { Experimental } \\
\text { conditions }\end{array}$ & $\begin{array}{l}\text { Experimental } \\
\text { temperature } \\
\left({ }^{\circ} \mathbf{C}\right)\end{array}$ & $\begin{array}{l}\text { Mean residual } \\
\text { concentration } \\
\text { at } \mathbf{7 2} \text { hours } \mathbf{( \% )}\end{array}$ & $\begin{array}{l}\text { Mean residual } \\
\text { concentration at } \\
\mathbf{7 2} \text { hours } \mathbf{( m g / m L})\end{array}$ & $\begin{array}{l}\text { Color of } \\
\text { solution at } \\
\mathbf{7 2} \text { hours }\end{array}$ & $\begin{array}{l}\text { Initial } \mathbf{p H} \\
\text { (buffered by } \\
\text { acetate buffer) }\end{array}$ & $\begin{array}{l}\mathbf{p H} \text { at } \\
\mathbf{7 2} \text { hours }\end{array}$ \\
\hline $10 \mathrm{mg} / \mathrm{mL}$ apomorphine & 25 & 99.4 & 9.9 & Colorless & 4.00 & 3.89 \\
$\mathrm{HCl} \mathrm{in} \mathrm{0.1 \%} \mathrm{AA}$ & 37 & 99.6 & 10.0 & Colorless & 4.00 & 3.92 \\
$10 \mathrm{mg} / \mathrm{mL}$ apomorphine & 25 & 99.5 & 10.0 & Colorless & 4.00 & 4.01 \\
$\mathrm{HCl} \mathrm{in} \mathrm{0.1 \%} \mathrm{EDTA}$ & 37 & 100.50 & 10.1 & Colorless & 4.00 & 3.98 \\
\hline
\end{tabular}

Note: Apomorphine $\mathrm{HCl}$ sample solutions for each assay were prepared in duplicate $(\mathrm{n}=2)$.

Abbreviation: AA, L-ascorbic acid.

be least stable in $0.1 \%$ SMB solution in this study, to the extent that the stability profile of apomorphine $\mathrm{HCl}$ solution (without any antioxidant) was more stable than when formulated in $0.1 \%$ SMB. This may indicate either SMB acts as a catalyst for the reaction when alone or specifically reacts with apomorphine under specific conditions. Abarca et $\mathrm{al}^{10}$ have proposed that the autoxidation of apomorphine $(\mathrm{m} / \mathrm{z} 268)$ was initiated by the transfer of two electrons and two protons from apomorphine to an oxygen molecule with the formation of an intermediate and $\mathrm{H}_{2} \mathrm{O}_{2}$ before the intermediate product was further oxidized by $\mathrm{H}_{2} \mathrm{O}_{2}$ into apomorphine o-quinone (oxoapomorphine; MW 263), which caused the characteristic greenish apomorphine aqueous solution. Compound $1(\mathrm{~m} / \mathrm{z} 264)$ matched the description by Abarca et $\mathrm{al}^{10}$ and this indicated that Compound 1 was very likely to be oxoapomorphine. An earlier study by Wilcox et $\mathrm{al}^{9}$ showed that the degradation of apomorphine $\mathrm{HCl}$ could be delayed by increasing the concentration of either AA or SMB in the solution. Nevertheless, Wilcox et $\mathrm{al}^{9}$ concluded that neither AA nor SMB could significantly delay the degradation for more than 1-3 days when the solutions were stored at room temperature. This means that concentration increments of antioxidant for a single agent antioxidant in solution could not significantly stabilize apomorphine $\mathrm{HCl}$ in solution. Therefore, it is proposed that the combination of $0.1 \% \mathrm{AA}$ and $0.1 \% \mathrm{SMB}$ is a superior antioxidant system for apomorphine $\mathrm{HCl}$ solution, compared to other antioxidants evaluated in this study. The antioxidant combination will provide additional antioxidant activity to the system. The most easily oxidized antioxidant would be expected to react with the dissolved oxygen in the system, leaving more antioxidant to minimize any oxidation of apomorphine, especially in the $50 \mu \mathrm{g} / \mathrm{mL}$ solution.

Decker et $\mathrm{al}^{8}$ indicated that apomorphine $\mathrm{HCl}$ solution (in $0.1 \% \mathrm{SMB}$ solutions) turned yellow in color after being subjected to autoclaving at $120^{\circ} \mathrm{C}$. The authors also suggested that yellow compound(s) might arise from the decomposition of apomorphine or a reaction between apomorphine and SMB ${ }^{8}$ The results from the section "Stability of apomorphine $\mathrm{HCl}$ in antioxidant solutions" supported this description where the yellow colored $50 \mu \mathrm{g} / \mathrm{mL}$ apomorphine $\mathrm{HCl}$ solution (in $0.1 \%$ SMB solution) was first observed on Day 11, Day 5 , and Day 3 at $25^{\circ} \mathrm{C}, 32^{\circ} \mathrm{C}$, and $37^{\circ} \mathrm{C}$, respectively. Thus, we propose that the yellowish or brownish compound formation in $50 \mu \mathrm{g} / \mathrm{mL}$ apomorphine $\mathrm{HCl}$ in $0.1 \%$ AA solution or $0.1 \%$ AA plus $0.1 \%$ EDTA solution may be attributed to either the degradant(s) of $\mathrm{AA}^{16,17}$ or a product of reactions between $\mathrm{AA}$ and apomorphine $\mathrm{HCl}$. It could also be the phenanthrene degradation product of apomorphine reported by Udvardy et al. ${ }^{1}$ As expected, the rate of degradation of apomorphine $\mathrm{HCl}$ (in all antioxidant solutions) increased with temperature, as shown by Wilcox et $\mathrm{al}^{9}$ previously. Notably, apomorphine $\mathrm{HCl} 50 \mu \mathrm{g} / \mathrm{mL}$ in $0.1 \%$ SMB solutions was stable for less than 5 hours at all experimental temperatures.

Moreover, from Figures 3-5, it is notable that the $50 \mu \mathrm{g} / \mathrm{mL}$ apomorphine $\mathrm{HCl}$ in $0.1 \% \mathrm{AA}$ did not follow first-order kinetics, where the rate of degradation of apomorphine slowed after 96 hours. This could be contributed to by a small $0.1 \mathrm{pH}$ unit reduction or diminished oxygen in the sample solutions. Burkman ${ }^{6}$ reported an exponential decay between the rate of degradation of apomorphine and the $\mathrm{pH}$ of apomorphine solutions. Similarly, a pH-dependent degradation pattern of the $50 \mu \mathrm{g} / \mathrm{mL}$ apomorphine $\mathrm{HCl}$ in $0.1 \% \mathrm{SMB}$ was also observed in the "Stability of $10 \mathrm{mg} / \mathrm{mL}$ and $50 \mu \mathrm{g} / \mathrm{mL}$ (with and without acetate buffer) apomorphine $\mathrm{HCl}$ in $0.1 \% \mathrm{SMB}$ solutions (purged with nitrogen)" section where apomorphine was more stable at a lower $\mathrm{pH}$, where the $50 \mu \mathrm{g} / \mathrm{mL}$ apomorphine $\mathrm{HCl}$ in $0.1 \% \mathrm{SMB}$ without buffer was stabilized by a $0.4 \mathrm{pH}$ unit reduction compared to its counterpart with buffer, which only had a $0.12 \mathrm{pH}$ unit reduction.

Interestingly, the results from sections "Stability of $10 \mathrm{mg} / \mathrm{mL}$ and $50 \mu \mathrm{g} / \mathrm{mL}$ (with and without acetate buffer) apomorphine $\mathrm{HCl}$ in $0.1 \% \mathrm{SMB}$ solutions (purged with 
nitrogen)" and "Stability of apomorphine $\mathrm{HCl}$ solutions (10 mg/mL; without nitrogen purging) in $0.1 \%$ AA solution and $0.1 \%$ EDTA solutions" showed that apomorphine $\mathrm{HCl}$ in all $10 \mathrm{mg} / \mathrm{mL}$ samples remained stable, where the concentration of sample solutions were within $95 \%-105 \%$ with no discoloration during the study period, when subjected to either $0.1 \%$ SMB solutions (purged with nitrogen), $0.1 \%$ AA solution (without nitrogen purging) or $0.1 \%$ EDTA solution (without nitrogen purging). As discussed in the "Introduction" section, the similar concentration-dependent degradation pattern was also observed by $\mathrm{Ng}$ Ying Kin et al, ${ }^{7}$ where the authors described that $0.1 \mathrm{mg} / \mathrm{mL}$ apomorphine $\mathrm{HCl}$ in $0.125 \% \mathrm{SBM}$ solution retained approximately $50 \%$ of its initial concentration after 6 weeks (with discoloration of solution after 3 weeks) when incubated at $4{ }^{\circ} \mathrm{C}$, while the counterpart $1 \mathrm{mg} / \mathrm{mL}$ apomorphine $\mathrm{HCl}$ in $0.125 \% \mathrm{SBM}$ solution retained at least $95 \%$ of its initial concentration under the same incubation conditions. Similarly, Priston and Sewell ${ }^{18}$ also found that $10 \mathrm{mg} / \mathrm{mL}$ apomorphine $\mathrm{HCl}$ formulated in $0.1 \% \mathrm{SMB}$ did not change in color and $\mathrm{pH}$ value with $98 \%$ remaining at $8^{\circ} \mathrm{C}$ after 14 days and with $96 \%$ remaining at $37^{\circ} \mathrm{C}$ after 7 days. The results from $\mathrm{Ng}$ Ying Kin et $\mathrm{al}^{7}$ and Priston Sewell ${ }^{18}$ indicated that apomorphine $\mathrm{HCl}$ solution with a higher concentration was more stable than its counterpart with a lower concentration. On the other hand, it is postulated that the $10 \mathrm{mg} / \mathrm{mL}$ apomorphine $\mathrm{HCl}$ in $0.1 \% \mathrm{AA}$ solution and the $10 \mathrm{mg} / \mathrm{mL}$ apomorphine $\mathrm{HCl}$ in $0.1 \%$ EDTA solution in the "Stability of apomorphine $\mathrm{HCl}$ solutions (10 mg/mL; without nitrogen purging) in $0.1 \%$ AA solution and $0.1 \%$ EDTA solutions" section might have changed color if the study period was prolonged. This postulation was based on the observation by Priston and Sewell, ${ }^{18}$ where $10 \mathrm{mg} / \mathrm{mL}$ apomorphine $\mathrm{HCl}$ formulated in $0.1 \%$ AA plus $0.05 \%$ EDTA solution darkened in color, changed in odor, and lowered in $\mathrm{pH}$ values over the 7-day incubation period at $8^{\circ} \mathrm{C}$ and $37^{\circ} \mathrm{C}$. However, $\mathrm{Ng}$ Ying Kin et $\mathrm{al}^{7}$ suggested that apomorphine has an unpredictable concentration-dependent discoloration pattern where the concentration of apomorphine $\mathrm{HCl}$ solution may affect its timing of discoloration. Therefore, the exact timing of discoloration of sample solutions in the section "Stability of apomorphine $\mathrm{HCl}$ solutions $(10 \mathrm{mg} / \mathrm{mL}$; without nitrogen purging) in $0.1 \%$ AA solution and $0.1 \%$ EDTA solutions" can only be determined by a study with a longer timeframe in the future.

From the results of the "Stability of $10 \mathrm{mg} / \mathrm{mL}$ and $50 \mu \mathrm{g} / \mathrm{mL}$ (with and without acetate buffer) apomorphine $\mathrm{HCl}$ in $0.1 \% \mathrm{SMB}$ solutions (purged with nitrogen)" section, $\mathrm{SMB}$, which is the antioxidant used in imitated apomorphine
$\mathrm{HCl}$ injection could not effectively prevent the degradation of apomorphine $\mathrm{HCl}$ in the formulation (even though the sample was purged with nitrogen), especially when the product was diluted, with yellow colored compound(s) forming during the decomposition. However, if the $10 \mathrm{mg} / \mathrm{mL}$ imitated apomorphine $\mathrm{HCl}$ injection (purged with nitrogen) was not diluted, it had a relatively low oxygen to drug ratio compared to its $50 \mu \mathrm{g} / \mathrm{mL}$ counterpart to oxygen in the stability study. It should be noted that the water which was used to prepare samples in the section "Stability of $10 \mathrm{mg} / \mathrm{mL}$ and $50 \mu \mathrm{g} / \mathrm{mL}$ (with and without acetate buffer) apomorphine $\mathrm{HCl}$ in $0.1 \% \mathrm{SMB}$ solutions (purged with nitrogen)" contained low residual dissolved oxygen even after purging with nitrogen. ${ }^{19,20}$ Furthermore, some limited reaeration of the sample solutions was possible when samples were withdrawn for analysis. Nevertheless, the study has found that the combination of $0.1 \% \mathrm{AA}$ and $0.1 \% \mathrm{SMB}$ solution provided the optimum antioxidant environment to limit the degradation, including visible color formation, for apomorphine $\mathrm{HCl}$, even at a temperature as high as $37^{\circ} \mathrm{C}$. Therefore, the authors recommend the addition of $0.1 \%$ AA to the current formulation of apomorphine $\mathrm{HCl}$ injection if it is to be used in other formulations.

One of the limitations of this study is that the duration of the study period is short (3-14 days), limiting the results to be applicable only to cases where apomorphine solution/ infusion is prepared for immediate issue to patients. Thus, the long-term stability of apomorphine $\mathrm{HCl}$ in $0.1 \% \mathrm{AA}$ and $0.1 \%$ SMB needs to be evaluated for long-term storage so that ready-to-use apomorphine infusion preparations with a lower concentration could be formulated for long-term infusions.

\section{Conclusion}

A combination of $0.1 \%$ AA $+0.1 \%$ SMB solution provided the most stable pharmaceutical environment for apomorphine $\mathrm{HCl}$ solution at a concentration $50 \mu \mathrm{g} / \mathrm{mL}$, where samples remained stable for at least 14 days at all experimental temperatures with respect to retention of concentration and absence of color formation. This enables the apomorphine injection to be further diluted and given as slow intravenous infusion for controlled administration. Apomorphine $\mathrm{HCl}$ $50 \mu \mathrm{g} / \mathrm{mL}$ in $0.1 \% \mathrm{SMB}$ solutions was stable for less than 5 hours at all experimental temperatures. Therefore, the addition of $0.1 \%$ AA to the current formulation of apomorphine $\mathrm{HCl}$ injection, which contains $\mathrm{SMB}$ as an antioxidant, is recommended if it is to be used as an additive. Notably, $10 \mathrm{mg} / \mathrm{mL}$ apomorphine $\mathrm{HCl}$ solution remained stable for 
at least 72 hours (as defined by the experimental protocol) when $0.1 \%$ SMB, $0.1 \%$ AA or $0.1 \%$ EDTA were employed in the solution. This suggests that the degradation rate and discoloration of apomorphine in different antioxidant solutions was affected by the initial concentration of apomorphine $\mathrm{HCl}$ in solution. Future research should establish longer term stability data, which could be utilized in the formulation of ready-to-use apomorphine infusion preparations with lower concentrations.

\section{Acknowledgments}

We thank the School of Pharmacy, Curtin University, Western Australia, for funding and providing the facilities for this research. We also would like to thank Dr Madhu Page-Sharp for providing assistance and advice in LC-MS analysis as well as Mr Liew Weng Heng and Ms Cheah Kit Yee for their contribution in statistical data analysis.

\section{Disclosure}

The authors report no conflicts of interest in this work.

\section{References}

1. Udvardy A, Gyulai Z, Sipos A. Extensive study of the autooxidation products of apomorphine and its pharmacologically active derivatives. J Mol Struct. 2011;1002(1-3):37-44.

2. Shabir GA. Step-by-step analytical methods validation and protocol in the quality system compliance industry. $J$ Valid Technol. 2005;10: 314-325.

3. Giesecke J. The absolute configuration of apomorphine. Acta Cryst. 1977; B33:302-303.

4. Subramony JA. Apomorphine in dopaminergic therapy. Mol Pharm. 2006; 3(4):380-385.

5. Garrido JM, Delerue-Matos C, Borges F, Macedo TR, Oliveira-Brett AM. New insights into the oxidation pathways of apomorphine. J Chem Soc. 2002;(10):1713-1717

6. Burkman AM. Some kinetic and thermodynamic characteristics of apomorphine degradation. J Pharm Sci. 1965;54:325-326.
7. Ng Ying Kin NM, Lal S, Thavundayil JX. Stability of apomorphine hydrochloride in aqueous sodium bisulphite solutions. Prog Neuropsychopharmacol Biol Psychiatry. 2001;25(7):1461-1468.

8. Decker WJ, Corby DG, Combs HF. A stable parenteral solution of apomorphine. Clin Toxicol. 1981;18(7):763-772.

9. Wilcox RE, Humphrey DW, Riffee WH, Smith RV. Stability of apomorphine in solutions containing ascorbic acid and bisulfite and effects of antioxidants on apomorphine-induced cage climbing and hypothermia in mice. J Pharm Sci. 1980;69(8):974-976.

10. Abarca B, Ballesteros R, Bielsa $P$, et al. Opposite vascular activity of (R)-apomorphine and its oxidised derivatives. Endothelium-dependent vasoconstriction induced by the auto-oxidation metabolite. Eur J Med Chem. 2003;38(5):501-511.

11. Priston MJ, Sewell GJ. Novel liquid chromatographic assay for the low-level determination of apomorphine in plasma. $J$ Chromatogr $B$ Biomed Appl. 1996;681(1):161-167.

12. Ingram WM, Priston MJ, Sewell GJ. Improved assay for R(-)apomorphine with application to clinical pharmacokinetic studies in Parkinson's disease. J Chromatogr B Analyt Technol Biomed Life Sci. 2006;831(1-2):1-7.

13. Snyder LR, Kirkland JJ, Dolan JW. Introduction to Modern Liquid Chromatography. New Jersey: John Wiley \& Sons; 2011.

14. Shrivastava S, Gupta V. Methods for the determination of limit of detection and limit of quantitation of the analytical methods. Chronicles of Young Scientists. 2011;2(1):21-25.

15. Chatrabhuji P, Pandya C, Patel M. HPLC Method for Determination of APIs in Pharmaceutical Formulation. USA: Lulu Press, Inc; 2015.

16. Bouwman Y, Le Brun P. Practical Pharmaceutics: An International Guideline for the Preparation, Care and Use of Medicinal Products. United Kingdom: Springer; 2015.

17. Kurata T, Sakurai Y. Degradation of L-ascorbic acid and mechanism of nonenzymic browning reaction: Part II. Non-oxidative degradation of L-ascorbic acid including the formation of 3-deoxy-L-pentosone Part III. Oxidative degradation of L-ascorbic acid (degradation of dehydroL-ascorbic acid). Agric Biol Chem. 1967;31(2):170-184.

18. Priston M, Sewell G. The analysis of apomorphine formulations for ambulatory infusions. Pharm Pharmacol Commun. 1995;1(2):91-94.

19. Butler IB, Schoonen MA, Rickard DT. Removal of dissolved oxygen from water: a comparison of four common techniques. Talanta. 1994; 41(2):211-215.

20. Degenhardt OS, Waters B, Rebelo-Cameirao A, Meyer A, Brunner H, Toltl NP. Comparison of the effectiveness of various deaeration techniques. Dissolut Technol. 2004;11(1):6-12.
Drug Design, Development and Therapy

\section{Publish your work in this journal}

Drug Design, Development and Therapy is an international, peerreviewed open-access journal that spans the spectrum of drug design and development through to clinical applications. Clinical outcomes, patient safety, and programs for the development and effective, safe, and sustained use of medicines are the features of the journal, which

\section{Dovepress}

has also been accepted for indexing on PubMed Central. The manuscript management system is completely online and includes a very quick and fair peer-review system, which is all easy to use. Visit http://www.dovepress.com/testimonials.php to read real quotes from published authors. 